\section{REFERENCES}

Abrams, A., Kegeles, G. \& Hottle, G. A. (1946). J. biol. Chem. 164, 63.

Balls, A. K. \& Lineweaver, H. (1939). J. biol. Chem. 130, 669.

Bronfenbrenner, J. J. \& Schlesinger, M. J. (1924). J. exp. Med. 39, 509.

Buehler, H. J., Schantz, E. J. \& Lamanna, C. (1947). J. biol. Chem. 169, 295.

Chistyakov, F. M. \& Rodopulo, A. R. (1943). J. Microbiol., Moscov, no. 9, 88 in Chem. Abstr. 39, 3323.

Dowmont, Y. P. \& Fruton, J. S. (1952). J. biol. Chem. 197, 271.

Hoover, S. R. \& Kokes, E. L. C. (1947). J. biol. Chem. 167, 199.

Kalmanson, G. M.\& Bronfenbrenner, J. (1943). J. Immunol. 47, 387.

Lamanna, C., Eklund, H. W. \& McElroy, O. E. (1946a). J. Bact. 52, 1.
Lamanna, C., Eklund, H. W. \& McElroy, O. E. (1946b). Science, 103, 613.

Lamanna, C. \& Glassman, H. N. (1947). J. Bact. 54, 575.

Lamanna, C. \& Lowenthal, J. P. (1951). J. Bact. 61, 751.

Littauer, U. (1951). Nature, Lond., 167, 994.

Markham, R. (1942). Biochem. J. 36, 790.

Moore, S. \& Stein, W. H. (1948). J. biol. Chem. 176, 367.

Nelson, C. (1927). J. infect. Dis. 41, 9.

Northrop, J. H., Kunitz, M. \& Herriott, R. M. (1948). Crystalline Enzymes, 2nd ed. New York: Columbia University Press.

Putnam, F. W., Lamanna, C. \& Sharp, D. G. (1948). J. biol. Chem. 176, 401.

Schubel, K. (1923). Arch. exp. Path. Pharmak. 96, 193.

Snipe, P. T. \& Sommer, H. (1928). J. infect. Dis. 43, 152.

Wagman, J. \& Bateman, J. B. (1951). Arch. Biochem. Biophys. 31, 424.

\title{
The Antithrombin Activity of Human Plasma
}

\author{
BY J. W. LYTTLETON* \\ (Received 15 February 1954)
}

The presence of an agent in serum capable of progressively inactivating the thrombin formed during the coagulation of blood or plasma has long been recognized. After it had been suggested that the factor involved in this action was protein in nature (Rettger, 1909), three main ideas were put forward as to the method of inactivation. Landsberg (1913) considered that thrombin was inactivated by a reversible non-specific adsorption on to serum albumin; Collingwood \& MacMahon (1912) held that thrombin was destroyed by a specific enzyme in serum; and Howell (1916) and his co-workers maintained that thrombin was rendered inactive by combination with a specific protein, the product of this combination being termed metathrombin.

More recent work has shown that antithrombin occurs in the albumin fraction of serum as obtained by salt precipitation (Lenggenhager, 1935; Quick, 1938; Stewart \& Rourke, 1940; Astrup \& Darling, 1942), but the factor itself has not been isolated. Astrup \& Darling (1942), working with bovine materials, described a method for the quantitative estimation of antithrombin based on the fact that a given quantity is capable of inactivating only a definite number of thrombin units, and that this inactivation is complete in $15 \mathrm{~min}$. Several observations recorded in the literature indicated that this method of measurement might not be directly

* Beit Memorial Research Fellow, The Lister Institute, London. Present address: Department of Scientific and Industrial Research, Plant Chemistry Laboratory, Palmerston North, N.Z. applicable to the estimation of human antithrombin. Both Collingwood \& MacMahon (1913) and Quick (1938), working with human materials, observed that thrombin inactivation continues for at least 30 min., while Herbert (1940) found that in a given time human serum would inactivate a definite fraction of the thrombin present, independent of its absolute concentration.

These apparent differences between the behaviour of human and bovine antithrombin indicated that a more complete examination of the reaction between human thrombin and human antithrombin might yield new information.

\section{MATERIALS AND METHODS}

Veronal buffer. Unless the contrary is stated, all the dilutions of materials used were carried out with a veronal buffer (Michaelis, 1930) of pH 7·3, $I=0 \cdot 15$. Two litres of this buffer contained $215 \mathrm{ml} .0 \cdot 2 \mathrm{~N} \cdot \mathrm{HCl}, 14 \cdot 43 \mathrm{~g}$. $\mathrm{NaCl}$, and $11.74 \mathrm{~g}$. Na barbiturate.

Fibrinogen. The estimation of antithrombin depends on measuring the inactivation of thrombin, and the strength of thrombin is measurable only in terms of the rate of coagulation of fibrinogen, whether this be native fibrinogen in plasma or a solution of fibrinogen purified by fractionation. In these experiments a solution of bovine fibrinogen was used as coagulation substrate, the fibrinogen being obtained by precipitation from bovine plasma by addition of $0 \cdot 11 \mathrm{vol}$. ether at $0^{\circ}$. The precipitate was washed with citrate saline containing $8 \%(v / v)$ ether, redissolved in citrate saline, and freeze-dried. The fibrinogen obtained in this way appears to be electrophoretically and ultracentrifugally homogeneous. It gives a satisfactory solution for measuring thrombin 
activity, and was used in preference to human fibrinogen because it was more readily obtainable in large quantities, and also because, unlike the human material, it became cloudy in the presence of thrombin immediately before coagulation, making accurate timing of the clotting very easy.

Thrombin. Human thrombin was prepared by a method developed from that devised by Kekwick, Mackay \& Record (1946) (see also Kekwick \& Mackay, 1954). After precipitating the fibrinogen from citrated human plasma by the addition of 0.11 vol. ether at $0^{\circ}$ the supernatant solution was adjusted to $\mathrm{pH} 5.3$ by the addition of $0.5 \mathrm{M}$ acetic acid (130-135 ml./1.). The precipitate of crude prothrombin formed at $0^{\circ}$ was centrifuged down and washed twice by resuspending in distilled water at $0^{\circ}$ and again centrifuging down. The washed precipitate was dissolved in veronal buffer $\mathrm{pH} 7 \cdot 3, I=0 \cdot 15$, and reprecipitated by reducing the ionic strength to $I=0.033$ and then adjusting the $\mathrm{pH}$ to 5.3 with $0 \cdot 1 \mathrm{M}$ acetic acid. After redissolving in citrate saline to $1 / 10$ original plasma volume and neutralizing, this prothrombin was converted into thrombin by addition of human placental thromboplastin and $\mathrm{CaCl}_{2}$. When the conversion was complete, the thrombin was partially purified by adding 0.1 vol. ether at $0^{\circ}$ and adjusting the $\mathrm{pH}$ to $5 \cdot 3$, when a large proportion of the contaminating impurities was precipitated. The thrombin solution was adjusted to $\mathrm{pH} 7 \cdot 3$ by dialysis against veronal buffer $\mathrm{pH} 7 \cdot 3, I=0 \cdot 15$, and freezedried in $10 \mathrm{ml}$. samples. This provided a suitable standard, effectively free from contamination with antithrombin. The thrombin activity was 93 units/mg. protein N.

Thrombin unit. The unit used was that defined by Owren (1947). According to this definition one thrombin unit is equal to the amount of thrombin which, in a volume of $1 \mathrm{ml}$. containing $0 \cdot 10-0.15 \mathrm{~g} . / 100 \mathrm{ml}$. human fibrinogen at $37^{\circ}$, $\mathrm{pH} 7 \cdot 3$, and $I=0 \cdot 15$, due to $\mathrm{NaCl}$, will cause a clot to form in 15 sec. This is a modification of the Iowa unit (Warner, Brinkhous \& Smith, 1936) in which the temperature used was $28^{\circ}$.

The veronal buffer used as a diluent in these experiments has been shown by Owren (1947) not to alter the coagulation time of fibrinogen from that in $0.15 \mathrm{M}-\mathrm{NaCl}$, in terms of which solution the thrombin unit is defined.

Measurement of thrombin activity. When solutions of ox fibrinogen are coagulated by human thrombin under standard conditions, the plot of the coagulation time against the reciprocal of the thrombin concentration gives an almost linear relation which can readily be used in measuring the thrombin activity of unknown solutions.

The coagulation was measured in $2 \times \frac{3}{8}$ in. thin-walled test tubes placed in a rack in a glass-walled water bath at $37^{\circ}$. Into each tube was pipetted $0.8 \mathrm{ml}$. bovine fibrinogen solution, diluted with veronal buffer to contain $0 \cdot 125 \mathrm{~g}$. protein $/ 100 \mathrm{ml}$; after $3 \mathrm{~min}$. temperature equilibration $0 \cdot 2 \mathrm{ml}$. thrombin solution, also at $37^{\circ}$, was injected from a capillary pipette by means of an attached hypodermic syringe, a stop-watch being started at the same instant. The tube was spun in its rack to produce a rotatory movement of its contents, which were under continuous observation, until coagulation took place. This was shown by the sudden immobilization of the small bubbles produced in the tube as a result of the rapid injection of the thrombin. With coagulation times of the order of 15 sec., the mean deviation of an individual measurement from the average was $0.2 \mathrm{sec}$; this increased to 2.0 sec. with coagulation times from 60 to 80 sec.
Antithrombin. The standard source of active antithrombin was defibrinated human plasma (DFP). A $200 \mathrm{ml}$. sample of fresh human plasma was taken from a plasma pool from sixty donors, the blood of each donor having been mixed with $120 \mathrm{ml} .3 \%(\mathrm{w} / \mathrm{v}) \mathrm{Na}$ citrate solution to give $540 \mathrm{ml}$. citrated blood. The plasma sample was diluted with an equal volume of veronal buffer, and the fibrinogen removed as fibrin by adding 1 unit of thrombin for every $20 \mathrm{ml}$. diluted plasma, while stirring rapidly to prevent clot formation. The defibrinated plasma, referred to subsequently as DFP, was freshly prepared every 2 weeks; and since material which had been stored for periods of up to 2 months showed no marked change in antithrombin activity, the antithrombin content of the DFP was taken as constant, and arbitrarily defined as containing 50 antithrombin units $/ \mathrm{ml}$.

Examination of antithrombin activity. Antithrombin activity was studied in all cases by incubating a sample of the material with thrombin in veronal buffer at $37^{\circ}$ and following the decay of thrombin activity by coagulating a solution of fibrinogen with samples removed at regular intervals. In this way a curve could be constructed of thrombin activity against time, enabling the course of the reaction between thrombin and antithrombin to be readily studied.

Electrophoresis. Electrophoretic analyses were carried out in a Tiselius apparatus in phosphate buffer, $\mathrm{pH} 8, I=0.2$, with protein concentrations of $2 \%(\mathrm{w} / \mathrm{v})$, determined refractometrically. Optical observations were made by the diagonal Schlieren method (Philpot, 1938), the light source being a high-pressure mercury arc from which monochromatic light, $\lambda=546 \mathrm{~m} \mu$., was isolated.

The same Tiselius apparatus was used in early work on separating the components of plasma by lateral displacement of the two intermediate sections of the U-tube at the conclusion of a run. In later work the flow-through apparatus (Kekwick, Lyttleton, Brewer \& Dreblow, 1951) was used to separate larger quantities of electrophoretically pure components.

\section{RESULTS}

\section{Reaction between human thrombin and human antithrombin}

Curves showing the thrombin inactivation due to defibrinated plasma (DFP) are given for two typical groups of incubation mixtures. In the first (Fig. 1) the concentration of thrombin was constant and the amount of DFP added was varied; while in the second (Fig. 2) the concentration of thrombin initially present was varied and the amount of DFP held constant.

When the proportion of DFP added to thrombin solutions exceeded a certain value, an immediate prolongation of the coagulation time occurred if the resulting mixture was used to coagulate a solution of fibrinogen. Unlike the progressive antithrombin action with which this paper is chiefly concerned, this immediate prolongation effect was still obtained after heating the DFP to $67^{\circ}$ for $10 \mathrm{~min}$. The complication of correcting for this effect, which did not become appreciable until the proportion of DFP in the incubation mixture exceeded $30 \%(\mathrm{v} / \mathrm{v})$, was avoided by keeping the proportion of DFP 
below $20 \%(v / v)$ in the majority of the experiments described. In such a case as curve 6 of Fig. 1, however, it was necessary to obtain calibration curves with fibrinogen solutions containing an equivalent amount of heated DFP, in order to calculate the thrombin concentration from the measured clotting time.

The curves of Figs. 1 and 2 show that under the conditions of the experiment the thrombin concentration seems to approach zero asymptotically at a rate which varies both with the concentration of thrombin and of DFP present. When the amount of DFP added is small, thrombin is still inactivated at a perceptible rate after $200-300 \mathrm{~min}$. (Fig. 1). The type of reaction involved thus differs from that found by Astrup \& Darling (1942) for ox blood, and

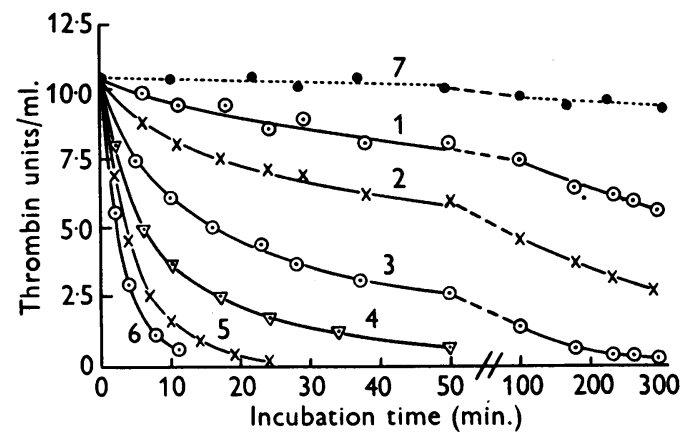

Fig. 1. Action of DFP on thrombin: initial thrombin concentration constant, DFP concentration varied. Mixtures 1-6 contained $1.0 \mathrm{ml}$. thrombin (53 units $/ \mathrm{ml}$.) and the following amounts of DFP: curve (1) $0.1 \mathrm{ml}$.; (2) $0.2 \mathrm{ml}$; (3) $0.4 \mathrm{ml}$.; (4) $0.7 \mathrm{ml}$.; (5) $1.3 \mathrm{ml}$; (6) $2.0 \mathrm{ml}$. Control mixture 7 contained no DFP. Volumes adjusted to $5 \mathrm{ml}$. with veronal buffer.

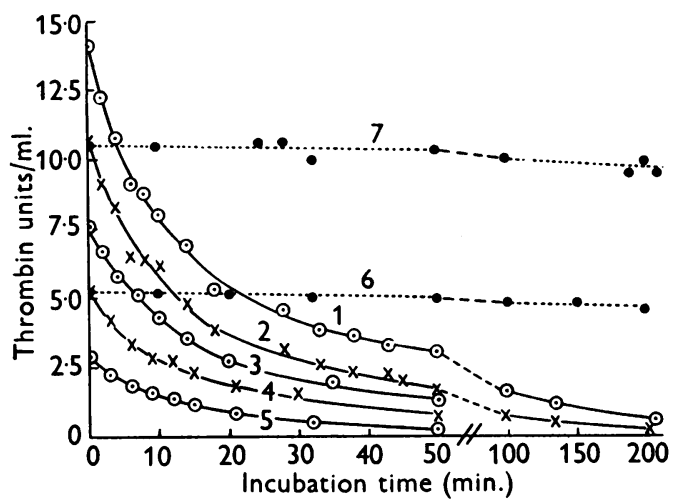

Fig. 2. Action of DFP on thrombin: DFP constant, initial thrombin concentration varied. Mixtures 1-5 contained $0.5 \mathrm{ml}$. DFP and the following amounts of thrombin (53 units/ml.): curve (1) $0.25 \mathrm{ml}$.; (2) $0.5 \mathrm{ml}$.; (3) $0.75 \mathrm{ml}$.; (4) $1.0 \mathrm{ml}$; (5) $1.25 \mathrm{ml}$. Control mixtures 6 and 7 contained no DFP and 0.5 and $1.0 \mathrm{ml}$. thrombin respectively. Volumes adjusted to $5 \mathrm{ml}$. with veronal buffer. their method of measuring antithrombin in terms of the number of thrombin units inactivated at the end of a reaction reaching completion in a short time (15 min.) is not applicable.

To estimate human antithrombin it is evident that the rate of thrombin inactivation rather than the ultimate amount of thrombin inactivated should be used, for Fig. 1 shows that this rate varies with the DFP concentration. To allow the amount of antithrombin in an unknown mixture to be determined from the decay curve produced when it was added to a standard thrombin solution, it was necessary to discover some property of the curves which could be related quantitatively to the known amount of DFP, or antithrombin, added to the system.

\section{Analysis of decay curves}

Kinetics of reaction. The reaction could not be described satisfactorily in terms either of first- or second-order equations. First-order constants $\left(k_{1}\right)$ were calculated for the curves of Figs. 1 and 2, assuming that during any one experiment the antithrombin concentration remained unchanged, and arbitrarily defining an antithrombin unit such that $1 \mathrm{ml}$. DFP contained 50 units of antithrombin, a definition used in all subsequent calculations.

The values obtained for $k_{1}$ decreased from 0.006 0.008 at $5 \mathrm{~min}$. to $0.002-0.003$ at $50 \mathrm{~min}$., but the uniformity of behaviour and small random variations in $k_{1}$ for the fivefold variation in initial thrombin concentration and 20 -fold variation in antithrombin concentration, indicated that the type of reaction occurring was constant within the concentration range considered.

Although an approximately constant value for the second-order reaction constant could be derived from the curves of Fig. 1 by assuming suitable values of initial antithrombin concentration, these values were not proportional to the known amounts of DFP added in each case.

$A$ method for estimation of antithrombin. If analysis in terms of reaction kinetics proves inapplicable to inactivation/time curves, the velocity of the reaction may be measured in terms either of the time required to produce a given percentage inactivation or of the percentage inactivation produced in a given time (Bodansky, 1937). Both of these methods gave values for the reaction velocity which were linearly related to the amount of antithrombin added to the system, provided that the reaction was not nearing completion.

The standard method adopted was to determine from the inactivation curve the percentage of thrombin inactivated in the first $10 \mathrm{~min}$. of the reaction, and to refer this to a calibration curve in which the $10 \mathrm{~min}$. percentage inactivation was plotted against the amount of DFP present in the 
system (Fig. 3). This calibration was valid for initial thrombin concentrations of 2-12 units/ml., and enabled the amount of antithrombin present in an unknown system to be determined in terms of DFP. The unit of antithrombin was arbitrarily defined as 1 unit $\equiv 0.02 \mathrm{ml}$. DFP, so in a reaction mixture of $5 \mathrm{ml}$., $0.1 \mathrm{ml}$. DFP gives 1 unit antithrombin $/ \mathrm{ml}$.

\section{Reduction of antithrombin activity due to incubation with thrombin}

The type of reaction between thrombin and antithrombin with its progressively decreasing firstorder constant $\left(k_{1}\right)$ suggests that antithrombin is removed from the system as the reaction proceeds. This was confirmed by incubating samples of thrombin solution and DFP together until negligible thrombin activity remained, and then measuring the remaining antithrombin activity (Fig. 4). Initially the amount of antithrombin activity removed increases linearly with the amount of thrombin inactivated, but the rate of removal decreases as the amount removed approaches the total amount present.

As a corollary to this observation it is to be expected that if a large excess of thrombin is added to a given amount of DFP, the antithrombin activity will be reduced to a very low value after a certain amount of thrombin has been inactivated, when the rate of thrombin decay will approach that of a control containing no antithrombin. This was confirmed by adding 1.5 antithrombin units to 25 thrombin units in $5 \mathrm{ml}$. veronal buffer. After $18 \mathrm{hr}$. incubation at $37^{\circ}, 15$ thrombin units had been inactivated, and the thrombin decay rate was approximately equal to that of the control.

\section{Effect of antithrombin on coagulation time of fibrinogen}

The variation in coagulation time on recalcification of plasma has been used as a method of measuring antithrombin activity (Tanturi \& Wetzel, 1949). This implies that antithrombin can

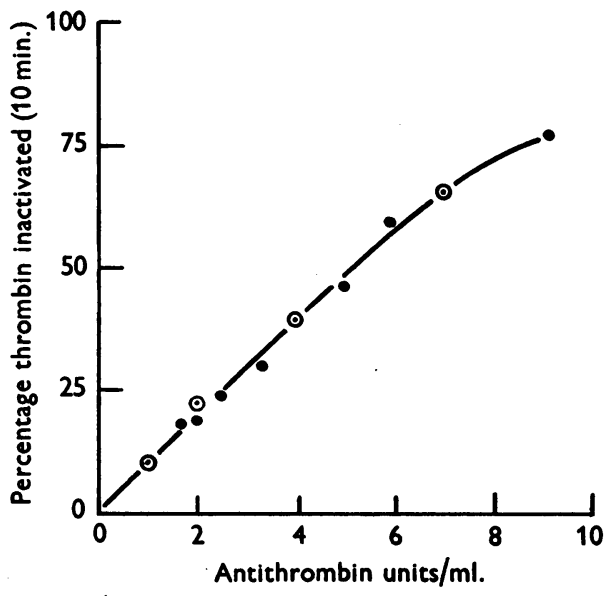

Fig. 3. Curve used for antithrombin estimation. ○, points derived from Fig. 1 ; $\bigcirc$, points derived from other experiments.



Fig. 4. Reduction in antithrombin activity caused by incubation with thrombin. Curve 1: twenty-five antithrombin units $(0.5 \mathrm{ml}$. DFP), thrombin as shown; curve 2: fifty antithrombin units (1.0 ml. DFP), thrombin as shown.

Table 1. Effect of antithrombin on coagulation time of fibrinogen

In each case $2 \cdot 0 \mathrm{ml}$. thrombin solution of appropriate concentration was added to give a total vol. of $8 \mathrm{ml}$.

Thrombin in reaction mixture (units/ml.)

$\begin{array}{lccc}\overbrace{1 \cdot 25} & \begin{array}{c}0.42 \\ \text { Coagulation time (sec.) }\end{array} & \\ & & & \\ & & & \\ 14 \cdot 0 & 31 & 79 & 185 \\ 18 \cdot 8 & 44 & 119 & 320 \\ 18 \cdot 0 & 43 & 123 & 410 \\ 17 \cdot 6 & 43 & 133 & 640\end{array}$

* Average of three measurements.

ml. fibrinogen $(1 \%, w / v$, in veronal buffer) added to

$5 \mathrm{ml}$. veronal buffer

$5 \mathrm{ml}$. heated DFP

$2.5 \mathrm{ml}$. heated DFP $+2.5 \mathrm{ml}$. unheated DFP

5 ml. unheated DFP 
influence the rate of coagulation of fibrinogen by thrombin. The conditions under which this influence was significant were investigated.

Progressive dilutions of thrombin (5 units $/ \mathrm{ml}$.) were used to coagulate fibrinogen solutions containing various proportions of heated ( $\left.10 \mathrm{~min} ., 57^{\circ}\right)$ and unheated DFP, the heated material being added to allow for the non-progressive prolongation of coagulation time already mentioned. The effect of active antithrombin in the unheated DFP is shown by Table 1. The immediate delaying action on coagulation, produced by both normal and heated DFP, was evident at all thrombin concentrations, whereas the additional effect of the progressive antithrombin was not significant until the coagulation time exceeded 100 sec., and not pronounced until coagulation times of the order of 400 sec. were involved. Measurement of the increase in coagulation time on addition of antithrombin to mixtures of thrombin and fibrinogen solutions is thus seen to be a very insensitive method of estimating antithrombin.

\section{Concentration and purification of antithrombin}

Identification of electrophoretic component containing antithrombin. Although the albumin fraction of serum is generally considered to be responsible for antithrombin activity (Lenggenhager, 1935; Quick, 1938; Astrup \& Darling, 1942), the albumin studied by these authors was prepared by salt fractionation in each case, and was possibly not electrophoretically pure. To investigate the activity of pure albumin, two electrophoretic runs

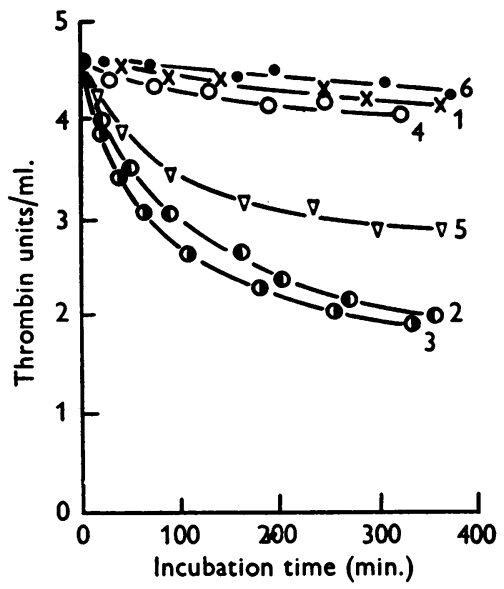

Fig. 5. Antithrombin activity of electrophoretically separated plasma fractions. Initial thrombin concentration 4.65 units $/ \mathrm{ml}$. in each case. Curve (1) $1 \mathrm{ml}$. albumin; (2) $1 \mathrm{ml} . \alpha-, \beta-, \gamma$-globulin fraction; (3) $1 \mathrm{ml}$. albumin $+\alpha-$ globulin; (4) 1 ml. $\beta$ - $+\gamma$-globulin; (5) $0.5 \mathrm{ml}$. albumin + $0.5 \mathrm{ml} . \alpha-, \beta-, \gamma$-globulin; (6) control. Volume adjusted in each case with veronal buffer to $5 \mathrm{ml}$. were carried out on DFP. In the first run a cut was made between the albumin and $\alpha$-globulins on the ascending side, enabling albumin to be separated from this side of the U-tube and $\alpha-, \beta-$, and $\gamma$ globulins from the descending side; while in the second run a cut was made between $\alpha$ - and $\beta$ globulins on the descending side, yielding $\beta$ - and $\gamma$ globulins on this side and albumin and $\alpha$-globulin on the ascending side. Inactivation curves were then measured on addition of each of these fractions to a solution of thrombin (Fig. 5).

The results show that electrophoretically pure albumin is not antithrombic; the antithrombin activity lies instead in the $\alpha$-globulins, and follows this fraction on separation. No activity is exhibited by $\beta$ - and $\gamma$-globulins, and a mixture of all the separated plasma components (curve 5) shows no more activity than that due to the $\alpha$-globulins. The antithrombin activity of human plasma thus belongs to the $\alpha$-globulin fraction alone.

A similar series of runs on fresh human serum showed that in serum as well as in DFP the antithrombin activity was associated with the $\alpha$ globulin fraction.

Concentration of antithrombin by salt precipitation. Fractionation of DFP by precipitation with $\mathrm{Na}_{2} \mathrm{SO}_{4}$ and $\left(\mathrm{NH}_{4}\right)_{2} \mathrm{SO}_{4}$ at a variety of concentrations and $\mathrm{pH}$ values resulted in no concentration of antithrombin. The only conditions under which antithrombin was precipitated to any great extent were at high concentrations of ammonium sulphate (above $70 \%$ saturated) and neutral $\mathrm{pH}$ values, or moderate concentration of ammonium sulphate (50\% saturated) and $\mathrm{pH}$ values below 4.5. Antithrombin thus appears to be among the more soluble globulins.

Concentration of antithrombin by ether precipitation. In the fractionation of human blood plasma by ether precipitation (Kekwick \& Mackay, 1948, 1954), the fibrinogen, prothrombin-containing globulins, and a $\beta-+\gamma$-globulin fraction are successively removed from citrated plasma. The supernatant remaining contains albumin as well as the more soluble fractions of the $\alpha$ - and $\beta$-globulin. From this supernatant a precipitate was obtained by lowering the $\mathrm{pH}$ to 5.0 at $-4^{\circ}$, the ether content remaining at $18 \%(\mathrm{v} / \mathrm{v})$ and the ionic strength at $0 \cdot 035$. This precipitate contained a high proportion $(30 \%)$ of $\alpha$-globulin, and will subsequently be referred to as $\alpha$-rich precipitate. The antithrombin activity of this precipitate per g. protein was $\mathbf{1 . 9}$ times that of DFP. Electrophoretic separation of the albumin $+\alpha$-globulin fraction of this material in the flow-through U-tube increased the specific activity to $3 \cdot 4$ times that of DFP.

This partially purified antithrombin gave thrombin decay curves which yielded values for $k_{1}$ (firstorder constant) which were within the range of 
those measured from Figs. 1 and 2. The kinetics of reaction thus seemed the same as with unfractionated DFP.

\section{Properties of antithrombin}

pH stability. The $\mathrm{pH}$ stability of antithrombin was examined by adjusting the $\mathrm{pH}$ of $10 \mathrm{ml}$. samples of DFP with $0.2 \mathrm{~N}-\mathrm{HCl}$ or $\mathrm{NaOH}$, and incubating for $4 \mathrm{hr}$. at $37^{\circ}$. The solutions were then neutralized and made up to a constant volume with $0 \cdot 15 \mathrm{M}-\mathrm{NaCl}$. Samples of each mixture were drawn off for $\mathrm{pH}$ measurement during the incubation. The antithrombin activities remaining after neutraliza. tion were measured (Fig. 6). The antithrombin activity of DFP is stable under the conditions used between pH's 6 and 9.5, but is particularly susceptible to $\mathrm{pH}$ above 9.5. A second experiment, carried out in conjunction with the results described in the next section, showed that the antithrombin activity of $\alpha$-rich precipitate was completely stable for $10 \mathrm{~min}$. at $37^{\circ}$ at $\mathrm{pH}$ values between 6 and 8.5.

Variation of activity with pH. Samples of the $\alpha$ rich precipitate were incubated with solutions of thrombin at various $\mathrm{pH}$ values, and the thrombin inactivation was followed. As addition of a reaction mixture to the fibrinogen solution would change its $\mathrm{pH}$, a modification of the usual method for estimating thrombin concentration was necessary to ensure that coagulation took place near $\mathrm{pH} 7 \cdot 3$. Samples $(0.2 \mathrm{ml}$.) of the reaction mixtures were added to $1.0 \mathrm{ml}$. veronal buffer, $\mathrm{pH} 7 \cdot 3$, at $37^{\circ}$, and $0.2 \mathrm{ml}$. of this sixfold dilution was added to $0.8 \mathrm{ml}$. fibrinogen solution in the usual way, so that coagulation took place under the standard conditions between $\mathrm{pH}$ 's $7 \cdot 2$ and 7.4. Control solutions of thrombin alone were also incubated at a series of $\mathrm{pH}$ values to determine how much of the thrombin inactivation occurring in the reaction mixtures was due to $\mathrm{pH}$ alone. The curves of Fig. 7 are corrected for this effect.

The previous section on $\mathrm{pH}$ stability indicates that the shape of the activity curve (Fig. 7) is not due to inactivation of antithrombin at $\mathrm{pH}$ values on either side of the point of maximum activity, but rather to a true $\mathrm{pH}$ optimum in the antithrombin activity in the vicinity of $\mathrm{pH} \mathbf{7 \cdot 4}$.

Temperature stability. In order to examine the temperature stability of antithrombin, $10 \mathrm{ml}$. samples of $\alpha$-rich precipitate, dissolved in veronal

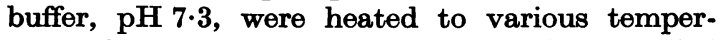
atures for $10 \mathrm{~min}$. in thin-walled glass tubes, chilled in cold water, and the antithrombin activities measured.

The results (Table 2) indicate that antithrombin is comparatively stable up to $50^{\circ}$, but at $60^{\circ}$ it is rapidly inactivated. At $37^{\circ}$, antithrombin loses no appreciable activity in $24 \mathrm{hr}$.
Influence of temperature on activity. Identical mixtures of thrombin and $\alpha$-rich precipitate were incubated at various temperatures and the course of the reaction followed by adding $0.2 \mathrm{ml}$. samples of the mixture to $1.0 \mathrm{ml}$. veronal buffer at $37^{\circ}$, then

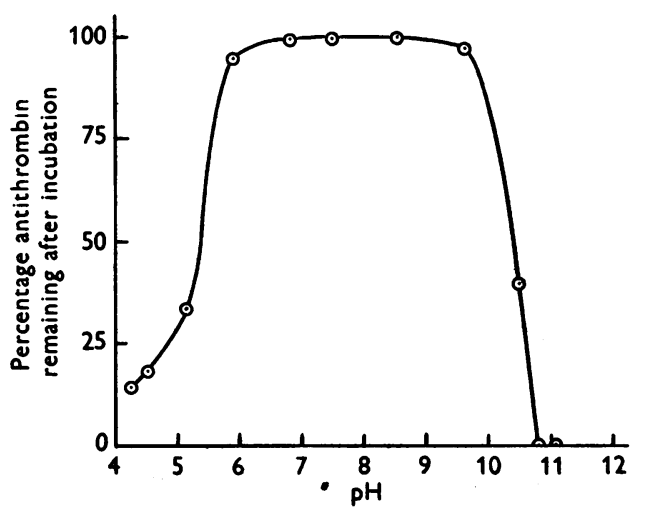

Fig. 6. Stability of antithrombin at different values of $\mathrm{pH}$; DFP incubated at the values of $\mathrm{pH}$ shown for $4 \mathrm{hr}$. at $37^{\circ}$.

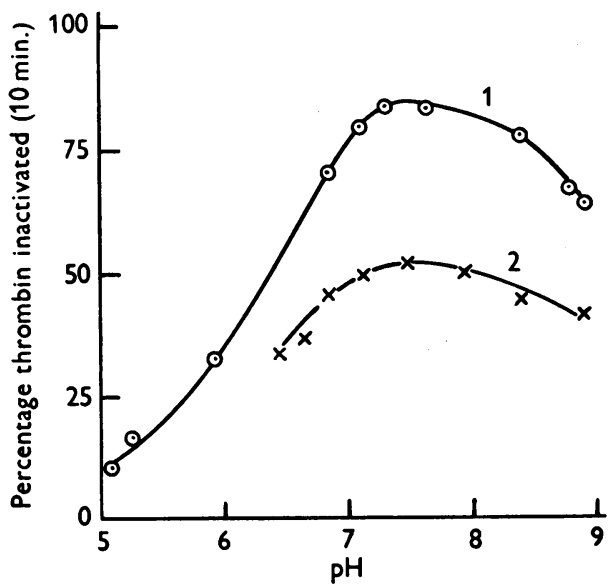

Fig. 7. Variation of antithrombin activity with $\mathrm{pH}$. Curve 1: $1.0 \mathrm{ml}$. thrombin (50 units $/ \mathrm{ml}$.) $+0.5 \mathrm{ml} . \alpha$-rich precipitate $+0 \cdot 15 \mathrm{~N}-\mathrm{NaOH}$ or $0.15 \mathrm{~N}-\mathrm{HCl}$; volume adjusted to $5 \mathrm{ml}$. with veronal buffer; curve 2: as above, except that $0.25 \mathrm{ml}$. $\alpha$-rich precipitate used in place of $0.5 \mathrm{ml}$.

Table 2. Temperature stability of antithrombin

$\begin{array}{ccc}\begin{array}{c}\text { Temperature of } \\ \text { incubation } \\ \left({ }^{\circ}\right)\end{array} & \begin{array}{c}\text { Antithrombin } \\ \text { remaining after } \\ \text { 10 min. incubation } \\ \text { (units/ml.) }\end{array} & \begin{array}{c}\text { Antithrombin } \\ \text { inactivated } \\ (\%)\end{array} \\ 35 & 50 & 0 \\ 40 & 49 & 2 \\ 45 & 51 & -2 \\ 50 & 50 & 0 \\ 55 & 41 & 18 \\ 60 & 5 & 90 \\ 65 & 0 & 100\end{array}$


using $0.2 \mathrm{ml}$. of this sixfold dilution to produce coagulation of $0.8 \mathrm{ml}$. fibrinogen solution in the usual way. This method avoided alteration of the temperature of the coagulation mixture, so enabling the normal calibration curve to be used. Control samples of thrombin alone were heated in a similar manner in order to allow for the thermal inactivation of thrombin.

The results of Table 3 show that the percentage thrombin inactivated reaches a broad maximum in the region of $35-40^{\circ}$. As antithrombin itself is completely stable under the conditions used, this represents a true temperature optimum for antithrombin activity.

Table 3. Variation of antithrombin activity with temperature

$\begin{array}{cc}\text { Temperature } & \begin{array}{c}\text { Thrombin } \\ \text { inactivated* } \\ \text { in } 10 \text { min. } \\ \left({ }^{\circ}\right)\end{array} \\ 25 & 39) \\ 30 & 44 \\ 35 & 49 \\ 40 & 49 \\ 45 & 46 \\ 50 & 43\end{array}$

* Inactivation corrected for spontaneous decay of thrombin.

\section{DISCUSSION}

The main problem with which this investigation has been concerned is that of the rate and the extent of the inactivation of human thrombin by human plasma components. The normal antithrombin action of blood has been shown to be progressive, the rate of thrombin inactivation depending on the concentration of both thrombin and antithrombin. In view of this, the most satisfactory method of measuring antithrombin activity is in terms of the velocity of thrombin inactivation. A direct measurement from the number of thrombin units inactivated is not permissible, although this method is used by Astrup \& Darling (1942) in estimating antithrombin of ox blood. Further, it is clear from Table 1 that the prolongation of coagulation time produced by addition of antithrombin to a mixture of thrombin and fibrinogen solutions is insensitive even to large changes in antithrombin concentration if thrombin is present in other than very low concentration. This observation is in accord with the evidence that a rise in the antithrombin content of blood does not produce a prolongation of coagulation time (Volkert, 1942; Koller \& Fritschy, 1947).

It does not seem necessary to postulate a competitive partition of thrombin between fibrinogen and antithrombin to account for the fact that antithrombin does not act as an anticoagulant, although this idea has been suggested (Quick, 1938).
The fact that antithrombin is not immediate in its action is adequate to explain why there is no significant delay of coagulation on increasing the concentration of antithrombin when coagulation times of less than 100 sec. are involved. The action of thrombin on fibrinogen certainly precedes the appearance of the clot, so that the removal of thrombin from the system by antithrombin would have to be extremely rapid to impose a delay on this early phase of the action on fibrinogen.

The non-progressive delaying action of defibrinated plasma on coagulation has not been thoroughly investigated here. The delay is not a non-specific colloid effect, for human $\gamma$-globulin solution containing the same weight of protein/unit vol. as defibrinated plasma does not produce it either before or after heating; and gum acacia solutions actually cause a considerable increase in the rate of coagulation. The delay may well be due to a reversible adsorption of thrombin on to albumin, as was suggested long ago by Landsberg (1913) and more recently by Gerendas (1948). It is, however, quite distinct from the true progressive antithrombin action, and a study of antithrombin must make use of methods which distinguish between the two effects.

Whatever may be the nature of the reaction causing the progressive decay of thrombin, it has been shown that the antithrombin responsible occurs in the $\alpha$-globulin fraction of both serum and defibrinated plasma, not in the albumin as previously supposed. Fractionation of defibrinated plasma by salt precipitation has not been successful in separating this antithrombic $\alpha$-globulin from albumin, and ether precipitation has achieved only a partial separation. The problem of purifying antithrombin is the difficult one of removing a small amount of active material from a large excess of contaminant, in this case albumin, with closely similar physical properties.

\section{SUMMARY}

1. The antithrombin action of defibrinated human plasma on human thrombin has been studied.

2. A method of estimating antithrombin based on the rate of thrombin inactivation has been developed.

3. A partial purification of antithrombin has been achieved by ether fractionation of plasma; the active fraction contained $30 \% \alpha$-globulin.

4. $\alpha$-Globulin isolated electrophoretically from this fraction was shown to carry the antithrombin activity.

5. Antithrombin is stable at $37^{\circ}$ between $\mathrm{pH} 6 \cdot 0$ and 8.5 and shows an optimum activity at $\mathrm{pH} \mathrm{7.3.}$

6. At $\mathrm{pH} \mathrm{7.3}$ antithrombin is comparatively 
stable up to $50^{\circ}$. The temperature optimum for antithrombin activity is between 35 and $40^{\circ}$.

My thanks are due to Dr R. A. Kekwick for much helpful advice and encouragement; to him and Miss M. Mackay for supply of human blood products; and to Dr I. A. Galloway, Ministry of Agriculture Research Station, Pirbright, for supply of ox blood.

\section{REFERENCES}

Astrup, T. \& Darling, S. (1942). Acta physiol. scand. 4, 293.

Bodansky, O. (1937). J. biol. Chem. 120, 555.

Collingwood, B. J. \& MacMahon, M. T. (1912). J. Physiol. $45,119$.

Collingwood, B. J. \& MacMahon, M. T. (1913). J. Physiol. 47, 44.

Gerendas, M. (1948). Hung. acta physiol. 1, 7.

Herbert, F. K. (1940). Biochem. J. 34, 1554.

Howell, W. H. (1916). Harvey Lect. xii, 1.

Kekwick, R. A., Lyttleton, J. W., Brewer, E. \& Dreblow, E. S. (1951). Biochem. J. 49, 253.
Kekwick, R. A. \& Mackay, M. E. (1948). Proc. 1st Int. Congr. Biochem. p. 147.

Kekwick, R. A. \& Mackay, M. E. (1954). The separation of protein fractions from human plasma with ether. Spec. Rep. Ser. med. Res. Counc., Lond., no. 286. London: H.M. Stationery Office.

Kekwick, R. A., Mackay, M. E. \& Record, B. R. (1946). Nature, Lond., 157, 629.

Koller, F. \& Fritschy, W. (1947). Helv. med. acta, 14, 263. Landsberg, M. (1913). Biochem. Z. 50, 245.

Lenggenhager, K. (1935). Helv. med. acta, 1, 527.

Michaelis, L. (1930). J. biol. Chem. 87, 33.

Owren, P. (1947). 'The Coagulation of Blood', Oslo: Gundersen.

Philpot, J. St L. (1938). Nature, Lond., 141, 283.

Quick, A. J. (1938). Amer. J. Physiol. 123, 712.

Rettger, L. I. (1909). Amer. J. Physiol. 24, 406.

Stewart, J. D. \& Rourke, G. M. (1940). J. clin. Invest. 19, 695.

Tanturi, C. A. \& Wetzel, N. C. (1949). Amer. J. med. Sci. 217, 410.

Volkert, M. (1942). Acta physiol. scand. 5, suppl. xv.

Warner, E. D., Brinkhous, K. M. \& Smith, H. P. (1936). Amer. J. Physiol. 114, 667.

\title{
The Antithrombin Activity of Heparin
}

\author{
By J. W. LYTTLETON*
}

(Received 15 February 1954)

Since its discovery by MacLean (1916) heparin has been recognized as the most important naturally occurring anticoagulant. It seems well established that its action is twofold; it inhibits the transformation of prothrombin to thrombin when accompanied by a cofactor present in plasma (Brinkhous, Smith, Warner \& Seegers, 1939), and it inhibits the action of thrombin on fibrinogen. It is this second action of heparin as an antithrombin that is studied here.

\section{MATERIALS AND METHODS}

'Heparin Vitrum', Stockholm, with an activity of 100 units/ mg. dry weight (Murray \& Best, 1938) was dissolved in small amounts to give solutions of 100 units $/ \mathrm{ml}$. in veronal buffer, $\mathrm{pH} 7 \cdot 3, I=0 \cdot 15$ (Michaelis, 1930), and freshly diluted as required. Toluidine blue (British Drug Houses Ltd.) was dissolved in veronal buffer to give a solution of $50 \mathrm{mg} . / \mathrm{ml}$. Thrombin, fibrinogen, and defibrinated plasma were the same as those described in the previous paper (Lyttleton, 1954).

Measurement of antithrombin activity of heparin. To study the antithrombin effect of heparin, the type of experiment

* Beit Memorial Research Fellow, The Lister Institute, London. Present address: Department of Scientific and Industrial Research, Plant Chemistry Laboratory, Palmerston North, N.Z. was the same as described in the previous paper (Lyttleton, 1954). Thrombin was incubated at $37^{\circ}$ with heparin and any other material being studied, and the decay in thrombin activity was followed by allowing samples withdrawn after various time intervals to coagulate a standard fibrinogen solution at $37^{\circ}$.

\section{RESULTS}

\section{Action of heparin on thrombin}

Samples (5.0 ml.) of thrombin (6.7 units $/ \mathrm{ml}$.) were incubated with various concentrations of heparin at $37^{\circ}$. Some of the curves thus obtained are shown in Fig. 1.

It is plain that heparin exerts two different effects on this thrombin preparation: (i) a slow progressive inactivation, predominant at low concentrations of heparin, and (ii) an immediate drop in thrombin activity, predominant at concentrations of heparin above 1.0 unit $/ \mathrm{ml}$.

From 0.05 to 0.5 unit $/ \mathrm{ml}$. of heparin, the rate of progressive inactivation of thrombin remains almost independent of heparin concentration, though this finding is not illustrated in Fig. 1. At 0.5 unit $/ \mathrm{ml}$. of heparin an immediate decrease in thrombin activity was observed, and further increase in heparin concentration caused a greater immediate decrease in 